Revue bibliographique pour le domaine irano-aryen

\title{
Francis Joannes. « Fabrics and Clothes from Mesopotamia during the Achaemenid and Seleucid Periods: The Textual References »
}

\section{Astrid Nunn}

\author{
(2) OpenEdition \\ Journals \\ Édition électronique \\ URL : http://journals.openedition.org/abstractairanica/42601 \\ DOI : 10.4000/abstractairanica.42601 \\ ISBN : 1961-960X \\ ISSN : 1961-960X \\ Éditeur : \\ CNRS (UMR 7528 Mondes iraniens et indiens), Éditions de l'IFRI
}

\section{Référence électronique}

Astrid Nunn, «Francis Joannes. «Fabrics and Clothes from Mesopotamia during the Achaemenid and Seleucid Periods: The Textual References » », Abstracta Iranica [En ligne], Volume 37-38-39 | 2018, document 14, mis en ligne le 10 mars 2018, consulté le 01 octobre 2020. URL : http://

journals.openedition.org/abstractairanica/42601; DOI : https://doi.org/10.4000/abstractairanica 42601

Ce document a été généré automatiquement le 1 octobre 2020.

Tous droits réservés 


\title{
Francis Joannes. « Fabrics and Clothes from Mesopotamia during the Achaemenid and Seleucid Periods: The Textual References »
}

\author{
Astrid Nunn
}

\section{RÉFÉRENCE}

Francis Joannes. « Fabrics and Clothes from Mesopotamia during the Achaemenid and Seleucid Periods: The Textual References », in: Catherine Breniquet et Cécile Michel (éds.). Wool Economy in the Ancient Near East and the Aegean: From the Beginnings of Sheep Husbandry to Institutional Textile Industry, (Ancient Textiles Series 17), Oxford, 2014, p. 453-464.

1 L'histoire des textiles prend une place de plus en plus importante dans la recherche du Proche Orient ancien. Ainsi ont été créées les Ancient Textiles Series (ATS) qui sont consacrées à l'histoire des textiles du néolithique à Alexandre le Grand et dont les éditrices sont particulièrement actives. Dans le volume 17 un article traite du vocabulaire accadien des textiles en contexte religieux (offrandes au temple, vêtements de statues et de prêtres), royal et privé. 


\section{AUTEURS}

\section{ASTRID NUNN}

Université de Munich 